\title{
Muscle Myoglobin as Determined by Electrophoresis in Thermally Acclimated Rat
}

\author{
Tomie OHNo and Akihiro Kuroshima* \\ Laboratory of Nutritional Physiology, Hokkaido University of Education, \\ Asahikawa, 070 Japan \\ *Department of Physiology, Asahikawa Medical College, \\ Asahikawa, 078 Japan
}

\begin{abstract}
Quantitative analysis of myoglobin $(\mathrm{Mb})$ was established using the sodium dodecyl sulfate-polyacrylamide slab gel electrophoresis in order to determine the influence of thermal acclimation on $\mathrm{Mb}$ levels in muscles. Myoglobin was measured in the red and white parts of quadriceps, soleus, diaphragm and heart of young adult male rats (11 weeks old). It was higher in the red muscle $(0.92 \pm 0.043 \mathrm{mg} / \mathrm{g}$ fresh weight $)$ than in the white muscle $(0.08 \pm 0.007)$, and similar in the red muscle and soleus $(1.17 \pm 0.117)$. Heart showed the highest level $(1.52 \pm 0.073)$ among the tissues studied. The level in diaphragm $(0.74 \pm 0.039)$ was intermediate between red muscle and heart. Cold acclimation $\left(5^{\circ} \mathrm{C}\right.$ for 4 weeks, 11 weeks old) caused significant increases in $\mathrm{Mb}$ levels in white muscle $(0.27 \pm 0.031, p<0.001)$, heart $(1.95 \pm 0.094, p<0.01)$, and diaphragm $(1.01 \pm 0.060, p<0.01)$, but not in red muscle and soleus. The rats reared in cold for many generations ( 20 generations at $5^{\circ} \mathrm{C}, 11$ weeks old) manifested significant increases in $\mathrm{Mb}$ levels of all tissues $(p<0.05-0.001)$ examined. Heat acclimation $\left(33^{\circ} \mathrm{C}\right.$ for 4 weeks, 11 weeks old) did not influence $\mathrm{Mb}$ levels of the tissues. The above findings suggest that skeletal muscle $\mathrm{Mb}$ may be partly involved in an enhanced thermogenesis in cold acclimation by favouring an oxidative capacity of muscles.
\end{abstract}

Key words: myoglobin, gel electrophoresis, cold acclimation, heat acclimation, skeletal muscle.

Brown adipose tissue has been claimed to be a major site of nonshivering thermogenesis, and this has been intensitively investigated (NiCHOLLs and LocKE, 1984). Although the brown adipose tissue is a principal effector of the increased nonshivering thermogenesis during cold acclimation, other tissues than brown adipose tissue could not be completely excluded. Especially, skeletal muscle, by

Received for publication May 5, 1986

* To whom reprints requests should be addressed. 
virtue of its large mass, has been regarded as a potential candidate for an alternative significant site of nonshivering thermogenesis. In fact, skeletal muscle has been shown to undergo histological, histochemical, and physiobiochemical changes in cold-acclimated animals that may be related to an enhanced capacity for heat production. Cold acclimation caused the increased total volume (BUSER et al., 1982), number (BeHrens and Himms-Hagen, 1977; YaHATA and Kuroshima, 1977) and modified size (Behrens and Himms-Hagen, 1977; Yahata and Kuroshima, 1977) of skeletal muscle mitochondria. Oxidative (succinate dehydrogenase) and lipid ( $\beta$ hydroxy butyrate dehydrogenase) enzymatic activities as assessed histochemically were shown to increase in the calf muscles of cold-acclimated rats (PoLlock et al., 1973), while glycolytic enzymes such as $\alpha$-glycerophosphate dehydrogenase did not change. Skeletal muscles from the cold-acclimated rats also exhibited increased $\mathrm{Na}^{+}-\mathrm{K}^{+}$-ATPase (GuERNSEY and STEvens, 1977) and lipoprotein lipase (BEGINHeICK and HeICK, 1977) activities. Cold exposure (JANSKÝ and HART, 1963) and noradrenaline infusion (JANSKÝ and HART, 1963; GRUBB and FOLK, 1976) stimulated oxygen consumption of the perfused hind limb of cold-acclimated rats.

Myoglobin ( $\mathrm{Mb})$ in the skeletal muscle is an important factor that controls an adequate oxygen supply to muscle mitochondria (WITTERNBERG, 1970) and, therefore, any modification of $\mathrm{Mb}$ concentration is expected to occur to meet oxygen requirement if thermogenic capacity or energy need of skeletal muscle is changed. In fact, $\mathrm{Mb}$ concentration was reported to increase in the exercising animals or the animals rearing at hypoxia (WITTENBERG, 1970). Recent studies, however, indicated that the exercise training did not increase skeletal muscle Mb level (MCDonaLD et al., 1984). It was also reported that $\mathrm{Mb}$ levels changed or did not change in the different muscles by exercise training (HARMS and HICKSON, 1983). Few studies have been reported so far about $\mathrm{Mb}$ in relation to cold acclimation. They showed significant increases in Mb levels of hind limb in mice, hamsters (CHAFFEE et al., 1965), and that of heart in guinea pigs (BUI and BANCHERO, 1980) due to cold acclimation. In these studies $\mathrm{Mb}$ concentrations were measured by indirect spectrophotometric methods (ReYNAFARJE, 1963; BUI and BANCHERO, 1980). The methods include the correction for hemoglobin present in the tissue assuming that coloured substances other than $\mathrm{Mb}$ and hemoglobin, such as cytochromes, do not influence the assay. In the present study we have established the method of $\mathrm{Mb}$ determination which specifically isolates and quantifies $\mathrm{Mb}$ by gel electrophoresis and examined the effect of thermal acclimation on $\mathrm{Mb}$ concentration in different types of muscles; red and white muscles of the quadriceps, intemediate muscle of soleus, heart, and diaphragm.

\section{METHODS AND MATERIALS}

Animals. Male Wistar rats (Shizuoka Laboratory Animal Center, Hamamatsu) were used in the study. At the start of the experiment the animals were 7 weeks old and weighed $180-190 \mathrm{~g}$. All animals were placed under the artificial 
lighting from 7:00 to 19:00, and provided an ad libitum diet of rat chow (Oriental MF, Oriental Yeast Co., Ltd., Tokyo) and tap water. Warm controls were kept at $25 \pm 1{ }^{\circ} \mathrm{C}$ and relative humidity of ca. $50 \%$. Cold-acclimated rats were exposed to $5 \pm 1{ }^{\circ} \mathrm{C}$ and heat-acclimated rats to $33 \pm 1{ }^{\circ} \mathrm{C}$ and relative humidity of ca. $30 \%$ continuously for 4 weeks. Rats reared in cold for 20 generations were also used in this study. Prepration of these animals was described elsewhere (MoRIYA et al., 1985).

Muscle sampling. The animals were decapitated and exsanguinated. The muscles chosen for the study were the fast twitch white muscle of superficial quadriceps with a low respiratory capacity, the fast twitch red muscle of deep quadriceps with a high respiratory capacity, the slow twitch red soleus with a moderately high respiratory capacity (WINDER and HoLLOSZY, 1977), heart and diaphragm. These muscles were rapidly dissected out and stored at $-30^{\circ} \mathrm{C}$ until $\mathrm{Mb}$ analysis.

$M b$ determination. The minced muscle was homogenized in the ice-cold acetic acid buffer $(0.01 \mathrm{M}, \mathrm{pH} 4.5,19.25 \mathrm{mg} / \mathrm{g}$ tissue) using a Polytron homogenizer followed by further homogenization with a Potter Elvehjem homogenizer in the iced water bath. The homogenate was centrifuged for $15 \mathrm{~min}$ at $22,600 \mathrm{~g}$ at $4^{\circ} \mathrm{C}$ and the extract supernatant was used for $\mathrm{Mb}$ determination.

Polyacrylamide slab gel electrophoresis. Gel electrophoresis was carried out by the method of LaEmmL (1970) using 15\% gel. The Mb samples for electrophoresis were prepared by incubating the extract supernatant mentioned above at $60^{\circ} \mathrm{C}$ for $10 \mathrm{~min}$ with $10 \%$ sodium dodecyl sulfate (SDS) $(2.65 \mathrm{ml}), 2$-mercaptoethanol $(0.3 \mathrm{ml})$, and saturated bromophenol blue solution $(0.05 \mathrm{ml})(\mathrm{v} / \mathrm{v}=1 / 1)$. The electrode buffer ( $\mathrm{pH} 8.4$ ) contained $0.025 \mathrm{~m}$ Tris, $0.192 \mathrm{M}$ glycine, and $0.1 \%$ SDS. Thirty $\mu$ sample solution was applied per sample well with a microsyringe and the electrophoresis was carried out with a current of $20 \mathrm{~mA}$ until the bromophenol blue marker reached the bottom of the gel (usually 3 to $4 \mathrm{~h}$ ). Staining of the proteins in the gel with Coomassie brilliant blue (CBB) and destaining the background gel were carried out as described previously (MURAKAMI and UCHIDA, 1985). The amount of $\mathrm{Mb}$ in a band was determined by quantification of the extracted CBB (FENNER et al., 1975). The eluted dye was analyzed for absorbance at $605 \mathrm{~nm}$ using Hitachi 101 Spectrophotometer. Sperm whale Mb was used as standard, since its biophysical nature was well examined (KATZ and DENIS, 1970). A known concentration of sperm whale $\mathrm{Mb}$, which was approximate to the tissue $\mathrm{Mb}$ level, was applied on all slab gels as an internal standard in order to correct any variations in staining from gel to gel.

Two-dimensional gel electrophoresis. Two-dimensional gel electrophoresis was performed according to the method of O'FARREL et al. (1977) as modified by MurAKAMI and UCHIDA (1984). The Mb sample was prepared by adding $50 \mu \mathrm{l}$ of solution $9.5 \mathrm{~m}$ urea $/ 2.3 \%$ Nodinet P-40/2.3\% 2-mercaptoethanol $/ 2 \%$ ampholytes to $50 \mu \mathrm{l}$ extract supernatant. Fifty $\mu \mathrm{l}$ of mixed solution was loaded onto firstdimensional cylindrical gel. Electrophoresis was carried out for $4 \mathrm{~h}$ at $400 \mathrm{~V}$ at room 
temperature. The second slab gel electrophoresis was performed at $5 \mathrm{~mA}$ for about $3 \mathrm{~h}$ so that the tracking dye neared the bottom of the tracking gel, followed by $20 \mathrm{~mA}$ for about $4 \mathrm{~h}$ until the dye reached the bottom of the separating gel.

Statistics. Unpaired $t$-test was used to evaluate the difference. All results were expressed as mean \pm standard error.

\section{RESULTS}

\section{Identification and quantification of $\mathrm{Mb}$}

Figure 1 shows electrophoretogram of sperm whale $\mathrm{Mb}$ in various concentrations. Standard solutions of $\mathrm{Mb}$ were prepared on the basis of specific extinction coefficient of sperm whale $\mathrm{Mb}, 90.0\left(E_{1 \mathrm{~cm}}^{1 \%}\right.$ at $\left.409 \mathrm{~nm}\right)$ (KATZ and DENIS, 1970). Total absorbances (net absorbances multiplied by the volume of the pyridine used for elution of the dye) for these $\mathrm{Mb}$ bands were plotted against the amounts of $\mathrm{Mb}$ applied to the gel (Fig. 2), indicating a linear relation between total absorbances and amounts of $\mathrm{Mb}$.

The actual gel pattern of muscle extract stained with CBB is presented in Fig. 3. The $\mathrm{Mb}$ bands, corresponding to the standard sperm whale $\mathrm{Mb}$, were shown to be well separated. The purity of the isolated $\mathrm{Mb}$ was monitored by the twodimensional gel electrophoresis with sperm whale $\mathrm{Mb}$ as shown in Fig. $4 \mathrm{a}-\mathrm{c}$. As a comparison, brown adipose tissue sample prepared similarly as muscle tissues was also run on the same slab gel in the second dimension, but no Mb spot was observed on the electrophoretogram (Fig. 4d).

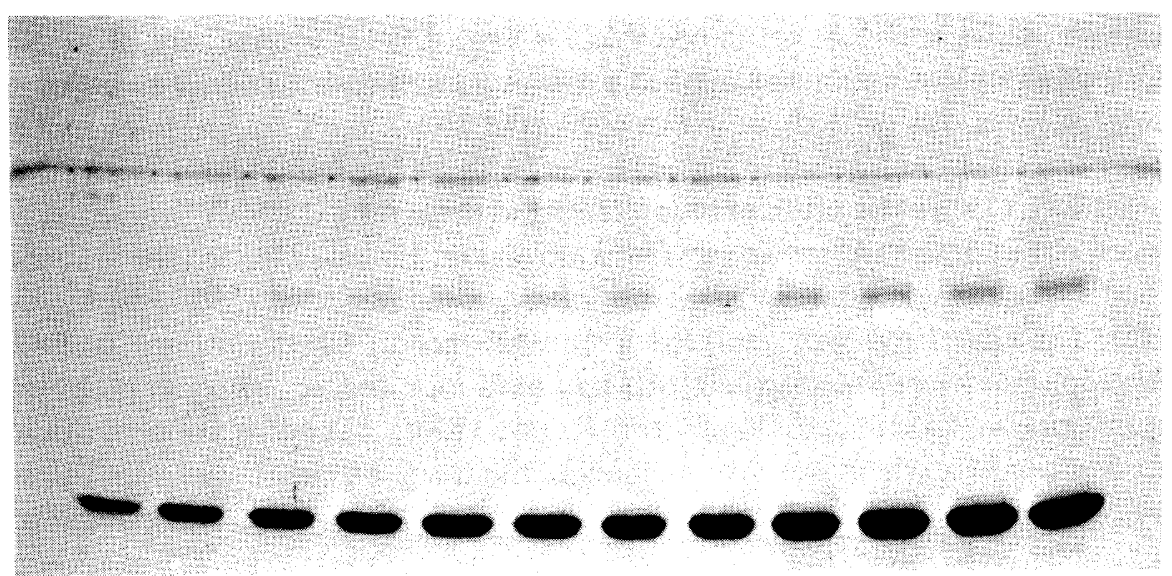

\section{$0.491 .02 \quad 1.47 \quad 1.892 .643 .003 .473 .884 .405 .285 .506 .00$}

\section{$\mathrm{Mb}(\mu \mathrm{g})$}

Fig. 1. Electrophoretograms of sperm whale myoglobin $(\mathrm{Mb})$ at various concentrations. 


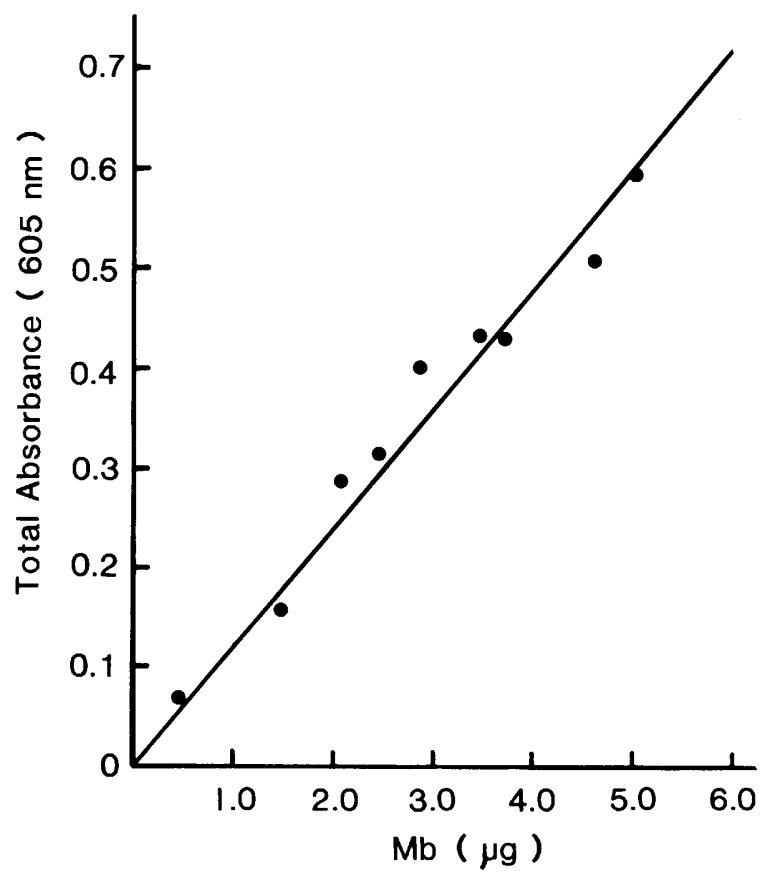

Fig. 2. Relationship between total absorbances and amounts of sperm whale myoglobin $(\mathrm{Mb})$.

Table 1. Myoglobin ( $\mathrm{Mb})$ concentration in cold-acclimated rats.

\begin{tabular}{lccccccc}
\hline & & \multicolumn{6}{c}{ Mb (mg/g fresh weight) } \\
\cline { 4 - 8 } Group & No. $\begin{array}{c}\text { Age } \\
\text { (week) }\end{array}$ & $\begin{array}{c}\text { Red } \\
\text { quadriceps }\end{array}$ & $\begin{array}{c}\text { White } \\
\text { quadriceps }\end{array}$ & Soleus & Heart & Diaphragm \\
\hline WC & 10 & 11 & $0.92 \pm 0.043$ & $0.08 \pm 0.007$ & $1.17 \pm 0.117$ & $1.52 \pm 0.073$ & $0.74 \pm 0.039$ \\
CA-4wk & 10 & 11 & $0.94 \pm 0.046$ & $0.27 \pm 0.031^{\mathrm{c}}$ & $1.37 \pm 0.196$ & $1.95 \pm 0.094^{\mathrm{b}}$ & $1.01 \pm 0.060^{\mathrm{b}}$ \\
C20G & 12 & 11 & $1.57 \pm 0.077^{\mathrm{c}}$ & $0.12 \pm 0.012^{\mathrm{a}}$ & $1.69 \pm 0.173^{\mathrm{a}}$ & $1.90 \pm 0.063^{\mathrm{c}}$ & $1.33 \pm 0.105^{\mathrm{b}}$ \\
\hline
\end{tabular}

WC, warm controls; CA, cold-acclimated rats; C20G, rats reared in cold for 20 generations. $p$ vs. WC: ${ }^{\mathrm{a}}<0.05,{ }^{\mathrm{b}}<0.01,{ }^{\mathrm{c}}<0.001$.

\section{Mb concentrations of the tissues}

The results are summarized in Tables 1 and 2. In the warm control groups the highest $\mathrm{Mb}$ level was found in the heart and the lowest in the white quadriceps; $\mathrm{Mb}$ level of red quadriceps was more than ten times as high as that of white quadriceps. Soleus showed a comparable value of $\mathrm{Mb}$ to that of red quadriceps. Diaphragm had the intermediate level of $\mathrm{Mb}$ between those of red quadriceps and heart. 


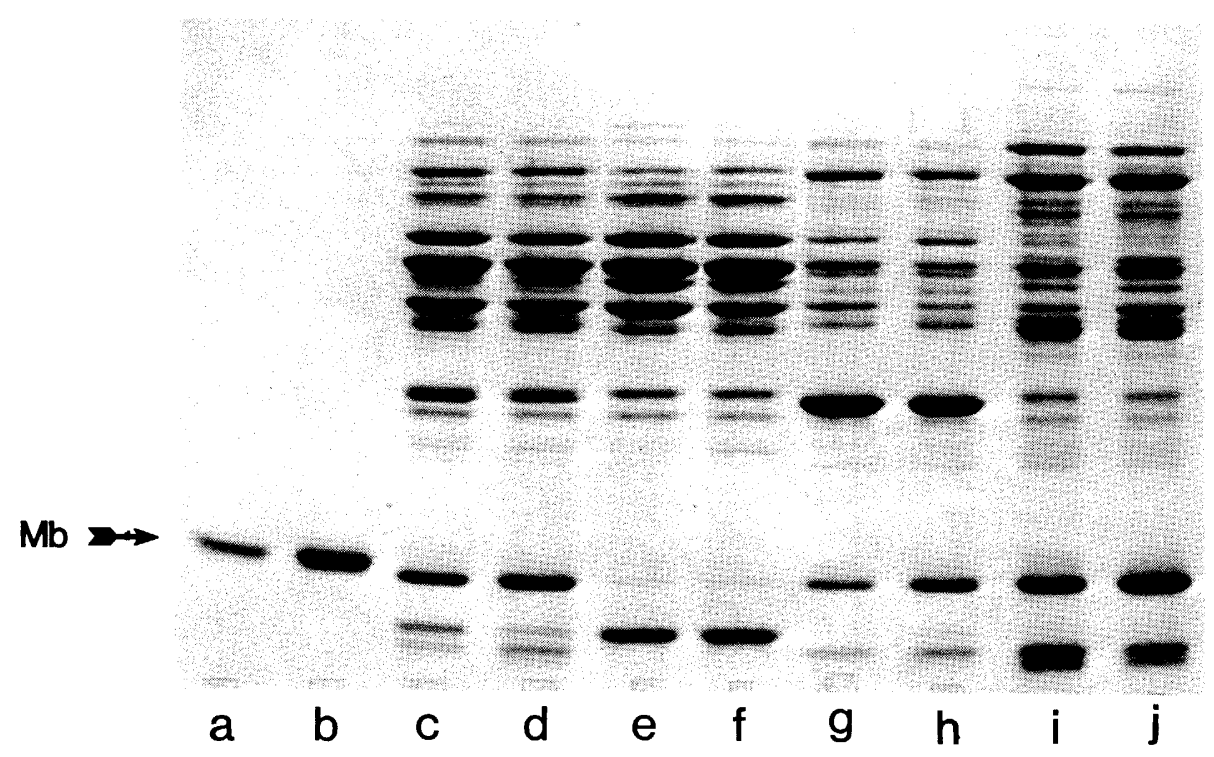

Fig. 3. Electrophoretograms of the samples of various muscles. a, sperm whale myoglobin $(\mathrm{Mb})(0.503 \mu \mathrm{g})$; b, sperm whale $\mathrm{Mb}(1.530 \mu \mathrm{g})$; c, red quadriceps (warm controls); $\mathrm{d}$, red quadriceps (reared in cold for 20 generations); e, white quadriceps (warm controls); f, white quadriceps (reared in cold for 20 generations); g, soleus (warm controls); h, soleus (reared in cold for 20 generations); i, heart (warm controls); $\mathrm{j}$, heart (reared in cold for 20 generations).

Table 2. Myoglobin (Mb) concentration in heat-acclimated rats.

\begin{tabular}{cccccccc}
\hline & & \multicolumn{6}{c}{ Mb (mg/g fresh weight) } \\
\cline { 4 - 8 } Group & No. $\begin{array}{c}\text { Age } \\
\text { (week) }\end{array}$ & $\begin{array}{c}\text { Red } \\
\text { quadriceps }\end{array}$ & $\begin{array}{c}\text { White } \\
\text { quadriceps }\end{array}$ & Soleus & Heart & Diaphragm \\
\hline WC & 10 & 11 & $1.00 \pm 0.071$ & $0.09 \pm 0.012$ & $1.14 \pm 0.061$ & $1.71 \pm 0.133$ & $0.95 \pm 0.039$ \\
HA & 10 & 11 & $0.86 \pm 0.069$ & $0.09 \pm 0.011$ & $1.14 \pm 0.076$ & $1.71 \pm 0.102$ & $0.91 \pm 0.052$ \\
\hline
\end{tabular}

WC, warm controls; HA, heat-acclimated rats.

Cold acclimation for 4 weeks with full development of nonshivering thermogenesis (JANSKÝ, 1973) effected significant elevations of Mb levels in the white quadriceps, heart, and diaphragm, but not in red quadriceps and soleus (Table 1). In the rats reared in cold successively for 20 generations $\mathrm{Mb}$ levels of all the tissues examined were significantly higher than those in the warm controls of the same age 


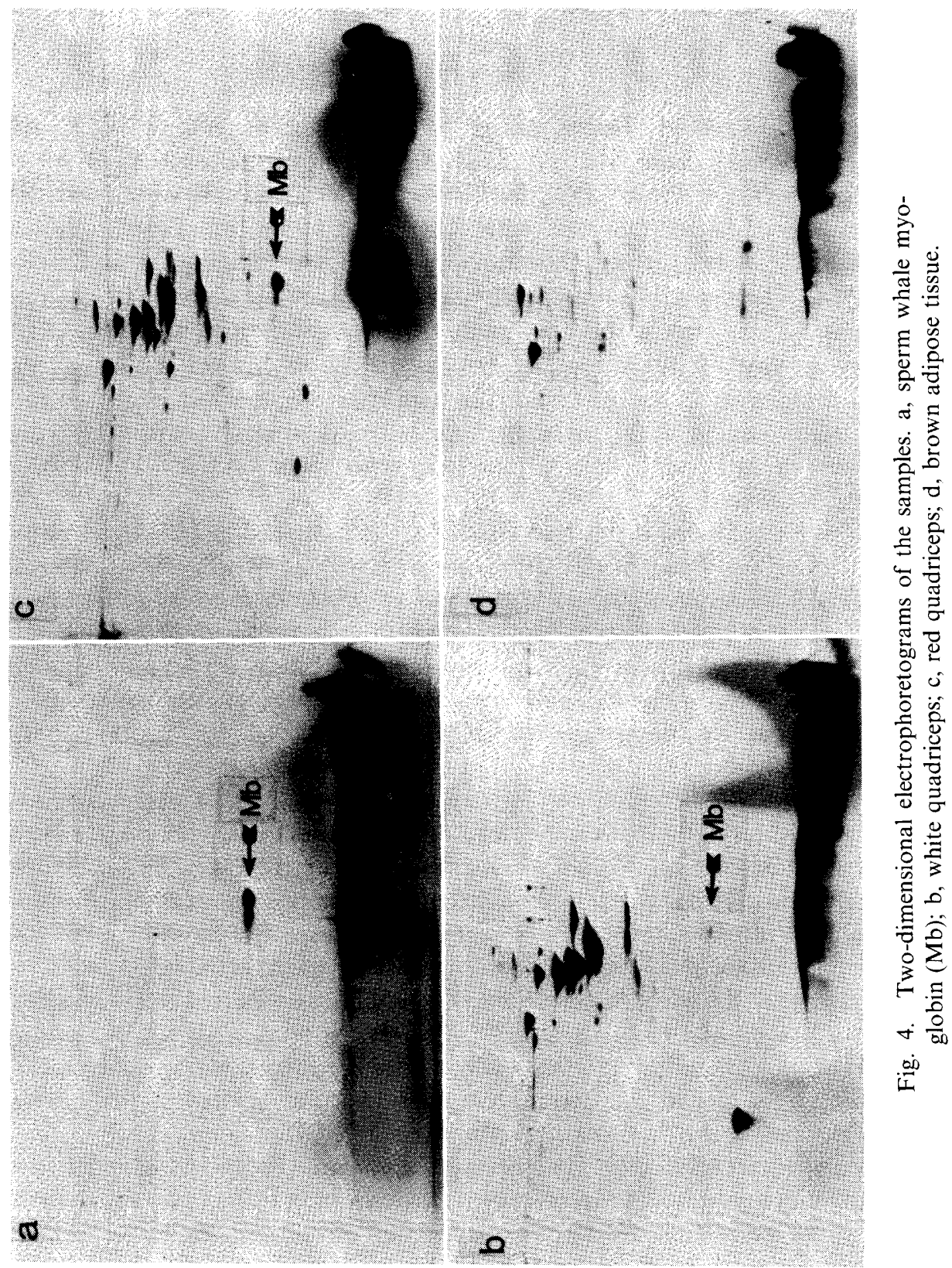

Vol. 36, No. 4, 1986 
(Table 1).

$\mathrm{Mb}$ levels of the muscles were not different in the heat-acclimated rats from those in the warm controls (Table 2).

\section{DISCUSSION}

$M b$ concentrations. The values of $\mathrm{Mb}$ levels in the present study were considerably lower as compared with those determined by the spectrophotometric method (REYNAFARJE, 1963; HARMS and HiCKSON, 1983), but the heart Mb level was about two times higher than the value determined by the photometric method followed by chromatography of the sample on carboxymethylcellulose (MCDONALD et al., 1984). The more direct approach with gel electrophoresis established in the present study may give a more accurate estimation of $\mathrm{Mb}$ in the tissues. The spectrophotometric method by REYNAFARJE (1963), most widely used for Mb, detected $\mathrm{Mb}$ activity in the brown adipose tissue (our unpublished result) which is known to be rich in other pigments such as mitochondrial cytochromes and hemoglobin in the vessels, while Mb spot was never found on the electrophoretogram of this tissue (Fig. 2).

It is well established that a high level of $\mathrm{Mb}$ is contained in a highly oxidative muscle with high activities of respiratory enzymes such as cytochrome oxidase and succinate dehydrogenase (HARMS and HiCKSON, 1983; Winder and Holloszy, 1977). It was confirmed in the present study that the muscles with high respiratory capacity have higher $\mathrm{Mb}$ levels. It was noted that $\mathrm{Mb}$ level in the red muscle of quadriceps was about 10 times higher than that in the white muscle of qudariceps. A similar difference was found elsewhere (HARMS and HICKSON, 1983), although Mb values were different from those in this report as mentioned above.

Changes in $M b$ levels in the thermally acclimated rats. Cold acclimation caused about threefold increase in $\mathrm{Mb}$ level of white quadriceps, while no significant changes in those of red quadriceps and intermediate muscle of soleus (Table 1). These three muscle fiber types have been shown to respond differently to the same physiological stimulation such as exercise, thyroid hormones and cold. Mitochondrial $\alpha$-glycerophosphate dehydrogenase increased in the red muscles, but dit not change in the white muscle in the thyroid hormone-treated rats (JANSSEN $e t$ al., 1978; Winder and Holloszy, 1977). The rat red quadriceps had the greater increases of mitochondrial enzymes such as citrate synthase and succinate dehydrogenase and also $\mathrm{Mb}$ concentration by training as compared with the white quadriceps and soleus (HARMS and Hickson, 1983). Succinate dehydrogenase (Debris and Filipchenko, 1975) and lipoprotein lipase (Begin-Heick and Heick, 1977) activities were activated specifically in the red muscle fibers of cold-acclimated rats. Creatine level and its uptake of soleus, but not of white muscle, gastrocnemius, was decreased in the cold-acclimated rats (Kurahashi and Kuroshima, 1978). These findings suggest an enhancement of oxidative thermogenesis in the more oxidative skeletal muscle by certain manipulations; site-specificity of muscular 
metabolic modifications induced by cold acclimation as well as exercise and hormones. Moreover, it was suggested from histochemical study (succinate dehydrogenase) that the white muscle fibers became more like the red muscle fibers with higher oxidative enzyme activity by cold acclimation (BEHRENS and HIMMS-HAGEN, 1977). The elevated $\mathrm{Mb}$ level in the white muscle of cold-acclimated rats may, thus, reflect a transition of its metabolism to a more oxidative direction, contributing to an improved thermogenesis in the skeletal muscles as a whole. Myoglobin levels also increased in the heart and diaphragm by 27 and $36 \%$ in the cold-acclimated rats, respectively, possibly resulting from the enhanced circulatory and respiratory functions (JANSKÝ, 1973). Changes in body activity might have influenced the tissue $\mathrm{Mb}$ levels in the present study. Exercise training was reported to elevate $\mathrm{Mb}$ levels of the heart (MCDonald et al., 1984) and skeletal muscles (HARMs and Hickson, 1983). However, it was reported that the amount of body activity was decreased in the cold-acclimated animals (BARRET and MounT, 1967). It is therefore very likely that the changes in $\mathrm{Mb}$ levels found in the present study were specific to cold acclimation. The present results accord with those reported in the gastrocnemius (white muscle) of cold-acclimated mice and hamsters (CHAFFEE et al., 1965) and in the heart ventricles of cold-acclimated guinea pigs (BUI and BANCHERO, 1980). Significant increase of $\mathrm{Mb}$ levels was also reported in the diaphragm and gastrocnemius in Alaskan snowshoe hares during winter as compared with those during summer (ROSENMANN and MORRISON, 1965). As mentioned earlier, however, Mb concentrations in these studies were measured by the spectrophotometric method and not compared among the different muscles. As shown here, cold acclimation with enhanced nonshivering thermogenesis (JANSKÝ, 1973) caused significant elevation of $\mathrm{Mb}$ in the white muscle, but not in the red muscle. The result differed in site-specificity from the previous studies that exercise training or thyroid hormones produced an increase in $\mathrm{Mb}$ of red muscle, but not in the white muscle (HARMS and Hickson, 1983; JANSSEN et al., 1978; WINDER and Holloszy, 1977). Accordingly, it is inferred that different mechanisms or factors are involved in the changes of $\mathrm{Mb}$ induced by cold acclimation as compared with exercise or thyroid hormones.

It was interestingly noted that $\mathrm{Mb}$ levels were more significantly elevated in all the tissues examined in the animals reared in the cold for many generations than in the warm controls of the same age (Table 1). These rats showed greater nonshivering thermogenesis than the usual cold-acclimated rats exposed to cold for periods of 2 to 8 weeks (MoriYa et al., 1985). Moreover, it was shown that even the rats reared in the warm for 3 generations after being reared for many generations in the cold exhibited much more nonshivering thermogenic capacity as compared to the warm controls. Such lasting consistency of cold adaptability in rats reared in cold for many generations may be explained by genetic changes or selection in cold tolerance. In any case, the higher $\mathrm{Mb}$ levels observed in the animals reared in the cold for many generations may contribute to the more improved thermogenic capacity than that in the usual cold-acclimated ones.

Depressed nonshivering thermogenesis was found in the heat-acclimated 
animals (Petrović and Marković-Giaja, 1973). Lowered resting metabolism (Rousset et al., 1984) and oxidative enzymes in the liver, but not in the kidney, heart and skeletal muscle (BEDRAK and SAMOILOFF, 1967) were also reported in the heat-acclimated rats. Any changes in Mb levels in the muscles were not obtained in the present study, suggesting that changes in muscle $\mathrm{Mb}$ are not related to the depressed metabolism, and tissues other than muscles are possibly involved.

Although no conclusive evidence in favour of a role for skeletal muscle in nonshivering thermogenesis yet exists, some indirect data have been presented as described in the Introduction, indicating that skeletal muscle may be involved in an enhanced thermogenesis induced by cold acclimation. The present findings on the changes in the $\mathrm{Mb}$ of skeletal muscles would also be another clue as to this problem.

We are grateful to Dr. U. Murakami, Department of Chemistry, Asahikawa Medical College for technical advice in gel electrophoresis and to Dr. T. Yahata for the care of the animals reared in cold for many generations.

\section{REFERENCES}

Barret, S. A. and Mount, L. E. (1967) Resistance to cold in mammals. In: Thermobiology, ed. by Rose, A. H., Academic Press, London and New York, pp. 411477.

BedraK, E. and Samoiloff, U. (1967) Comparative effects of aldosterone and heat acclimatization on oxidative enzymes in rat tissue. Can. J. Physiol. Pharmacol., 45: 717722.

Begin-Heick, N. and Heick, H. M. C. (1977) Increased lipoprotein lipase activity of skeletal muscle in cold-acclimated rats. Can. J. Biochem., 55: 1241-1243.

Behrens, W. A. and Himms-Hagen, J. (1977) Alterations in skeletal muscle mitochondria of cold-acclimated rats: Association with enhanced metabolic responses to noradrenaline. J. Bioenerg. Biomembr., 9: 41-63.

Bui, M. V. and Banchero, N. (1980) Effects of chronic exposure to cold or hypoxia on ventricular weights and ventricular myoglobin concentrations in guinea pigs during growth. Pflügers Arch., 385: 155-160.

Buser, K. S., Kopp, B., GeHr, P., Weibel, E. R., and Hoppeler, H. (1982) Effect of cold environment on skeletal muscle mitochondria in growing rats. Cell Tissue Res., 225: $427-436$.

Chaffee, R. R. J., Cassuto, Y., and Horvath, S. M. (1965) Studies on the effects of cold acclimation on myoglobin levels in sparrows, mice, hamsters, and monkeys. Can. J. Physiol. Pharmacol., 43: 1021-1025.

DeBris, V. I. and FilipCHENKo, R. E. (1975) Histochemical and cytophotometrical study on succinate dehydrogenase activity in skeletal muscle of cold-adapted rat. In: Physiological Adaptation to Cold, High-land and Subarctic Environments, ed. by IvanOv, K. P. and SLONim, A. D., Nauka, Novosibirsk, pp. 17-25.

Fenner, C., Taut, R. R., Mason, D. T., and Wikman-Coffelt, J. (1975) Quantification of Coomassie blue brilliant stained proteins in polyacrylamide gels based on analyses of eluted dye. Anal. Biochem., 63: 595-602.

GruBb, B. and FolK, G. E., Jr. (1976) Effect of cold acclimation on norepinephrine 
stimulated oxygen consumption in muscle. J. Comp. Physiol., 110: 217-226.

Guernsey, D. L. and Stevens, E. D. (1977) The cell membrane sodium pump as a mechanism for increasing thermogenesis during cold acclimation in rat. Science, 196: 908-910.

HaRms, S. J. and Hickson, R. C. (1983) Skeletal muscle mitochondria and myoglobin, endurance, and intensity of training. J. Appl. Physiol., 54: 798-802.

JANSKÝ, L. (1973) Non-shivering thermogenesis and its thermoregulatory significance. Biol. Rev., 48: 85-132.

JANSKÝ, L. and HART, J. S. (1963) Participation of skeletal muscle and kidney during nonshivering thermogenesis in cold-acclimated rats. Can. J. Physiol. Pharmacol., 41: 953-964.

Janssen, J. W., von Hardeveld, C., and Kassenaar, A. A. H. (1978) Evidence for a different response of red and white skeletal muscle of the rat in different thyroid states. Acta Endocrinol., 87: 768-775.

KatZ, S. and Denis, J. (1970) Partial molar volume and gel electrophoretic studies of sperm whale myoglobin and apomyoglobin, native and urea denatured. Biochim. Biophys. Acta, 207: 331-339.

Kurahashi, M. and Kuroshima, A. (1978) Creatine metabolism in skeletal muscle of coldacclimated rats. J. Appl. Physiol., 44: 12-16.

LAEMmLI, U. K. (1970) Cleavage of structural proteins during the assembly of the head bacteriophage T4. Nature, 277: 680-685.

McDonald, R., Hegenauer, J., Sucec, A., and Saltman, P. (1984) Effects of iron deficiency and exercise on myoglobin in rats. Eur. J. Appl. Physiol., 52: 414-419.

Moriya, K., Yahata, T., and Kuroshima, A. (1985) Lasting consistency of cold adaptability in rats reared in cold for many generations. Jpn. J. Physiol., 35: 423-442.

MuRAKAmI, U. and Uchida, K. (1984) Two-dimensional electrophoresis of troponin complex with nonequiribrium $\mathrm{pH}$ gradient-sodium dodecyl sulfate polyacrylamide slab gel. J. Biochem., 95: 1577-1584.

MuraKami, U. and UCHIDA, K. (1985) Contents of myofibrillar proteins in cardiac, skeletal, and smooth muscles. J. Biochem., 98: 187-197.

Nicholls, D. G. and Locke, R. M. (1984) Thermogenic mechanisms in brown fat. Physiol. Rev., 64: 1-64.

O'Farrel, P. Z., Goodman, H. M., and O'Farrel, P. H. (1977) High resolution twodimensional electrophoresis of basic as well as acidic proteins. Cell, 12: 1133-1142.

Petrovic, V. M. and Markovic-Giaja, L. (1973) A comparative study of the calorigenic action of noradrenaline in the rat and ground squirrel adapted to different temperatures. Experientia, 29: 1295-1296.

Pollock, M., Cable, W. J. L., and Tiller, S. H. (1973) Skeletal muscle metabolism in cold acclimation. In: Basic Research in Myology. Part 1, ed. by KaKUlas, B. A., American Elsevier, New York, pp. 102-108.

ReYnAFARJE, B. (1963) Simplified method for the determination of myoglobin. J. Lab. Clin. Med., 61: 138-145.

Rosenmann, M. and Morrison, P. (1965) Seasonal augmentation of myoglobin in the snowshoe hare. J. Biol. Chem., 240: 3353-3356.

Rousset, B., Cure, M., Jordan, D., Kervran, A., Bornet, H., and Mornex, R. (1984) Metabolic alterations induced by chronic heat exposure in the rat: The involvement of thyroid function. Pfiügers Arch., 401: 64-70.

Winder, W. W. and Holloszy, J. O. (1977) Response of mitochondria of different types of skeletal muscle to thyrotoxicosis. Am. J. Physiol., 232: C180-C184. 
WittenberG, J. B. (1970) Myoglobin-facilitated oxygen diffusion: Role of myoglobin in oxygen entry into muscle. Physiol. Rev., 50: 559-636.

Yahata, T. and Kuroshima, A. (1977) Changes in fine structure of rat skeletal muscle related to cold acclimation. Hokkaido J. Med. Sci., 52: 63-67. 